\title{
Common home: our responsibility, our survival
}

Michell Ângelo Marques Araújo ${ }^{1}$

We have noticed how the reflections raised in the 2016 Ecumenical Fraternity Campaign are appropriate, timely and mobilizing to protect, promote and ensure life, and its theme is - "common home: our responsibility". Due to the fact that this year has an ecumenical character, the campaign is not limited to the Catholic scope, but includes the Churches that take part in the Brazilian National Council of Christian Churches (as per its Portuguese acronym), thus inviting society to a broader discussion about this issue, with an emphasis on sewage disposal.

In the health area, this issue is not new, because, during the XIX century, Florence Nightingale, Nursing icon, had already analyzed sewage disposal as a fundamental condition for the patients' health. Nevertheless, it was from the 70s of the XX century, with the Alma-Ata Conference and other international conferences on health promotion, that health started to be seen more broadly, not merely as the absence of disease, but including a series of conditions to promote the welfare of populations and ensure minimum conditions of dignity and citizenship to persons.

The official campaign document unveils us an overview of the seriousness of the situation and incites us to think in dimensions for a concrete action in the reality that Brazil is facing nowadays. The first dimension is the JUDGING, based on the biblical text: "to see the right sprouting just as a source and the justice running just as a stream that does not dry out" (Amos 5:24), which proves that the fight for decent conditions is a question of justice and an imperative against greed, easy profit, marginalization of poor persons and privilege of a few ones. The second dimension is the ACTING. Due to its ecumenical character, it highlights the need for dialogue with all parties, without distinction, and suggests concrete actions from the elaboration of healthy public policies and a citizen attitude that reminds us that "the sewage treatment of a given place starts from the treatment of the sewage of the heart itself", which is a task that includes ordinary people, workers, managers and governments.

The Northeastern Nursing Network Journal - Rev Rene, aware of its commitment and duty to promote a scientific production capable of transforming reality, has kept its editorial policy in 2016, which intends to encourage promotion of life and health for everyone, especially in the current days, when the political and economic conditions are unfavorable and the democratic institutions are endangered. Thus, we further strengthen the need to ensure the achievements of a unified, universal, comprehensive and equitable health system. It is concerned not just with the responsibility with our "Common Home", but mainly with its survival.

${ }^{1}$ Unversidade Federal do Ceará. Fortaleza, CE, Brazil.

Corresponding author: Michell Ângelo Marques Araújo

Rua Alexandre Baraúna, 1115 - Rodolfo Teófilo. CEP: 60430-160 - Fortaleza, CE, Brazil. E-mail: micenf@yahoo.com.br 